\title{
Incremento della densità minerale ossea con un secondo ciclo di dodici mesi di romosozumab dopo placebo o denosumab
}

\author{
Salvatore Minisola ${ }^{1}$
}

Pubblicato online: 13 luglio 2020

(c) The Author(s) 2020

Commento a:

Bone mineral density gain with a second 12-month course of romosozumab following placebo or denosumab.

D.L. Kendler, H.G. Bone, F. Massari, E. Gielen, S. Palcios, J. Maddox, C. Yan, S. Yue, R.V. Dinavahi, C. Libanati, A. Grauer.

Osteoporosis Int (2019) 30:2437-2488

L'osteoporosi è una malattia cronica pressoché esclusiva dell'età adulta, la cui principale conseguenza clinica e sociale è rappresentata dalle fratture.

Per definizione, tutte le malattie croniche necessitano di terapia cronica sin dal momento della diagnosi. Per esempio, i pazienti affetti da diabete mellito, broncopneumopatia cronica ostruttiva, ipertensione arteriosa e artrite reumatoide (solo per citare le più comuni malattie croniche) devono essere sottoposti a terapia per tutto il corso della vita.

Anche l'osteoporosi non può esimersi da tali considerazioni; tuttavia, i regimi terapeutici di lunga durata sono, in genere, mal tollerati dai pazienti. Nel caso specifico dell'osteoporosi si aggiunge anche la paura degli effetti collaterali dei farmaci enfatizzata oltre misura dai media [1].

La possibilità di disporre di più farmaci con diverso meccanismo d'azione può rappresentare un'alternativa interessante per intercalare i farmaci e prolungare il periodo di trattamento. Ciò, in teoria, può ridurre anche gli effetti collaterali di una somministrazione prolungata di un singolo farmaco.

\footnotetext{
S. Minisola

salvatore.minisola@uniroma1.it

1 Dipartimento di Scienze Cliniche, Internistiche, Anestesiologiche e Cardiovascolari, "Sapienza" Università di Roma, Roma, Italia
}

$\grave{E}$ in questo ambito che il lavoro di Kendler e collaboratori [2] rappresenta un importante passo avanti. In sostanza dimostra come l'alternanza di un farmaco che stimola la formazione ossea (romosozumab) con uno che inibisce la perdita di massa scheletrica (denosumab) è in grado di aumentare in maniera significativa i valori di densità minerale ossea rispetto al valore iniziale $(+22,1$ e $7,3 \%$ a livello lombare e femorale, rispettivamente, dopo una sequenza di romosozumab per 24 mesi, denosumab 12 mesi e ancora romosozumab per ulteriori 12 mesi). Poiché la densità minerale ossea contribuisce per la gran parte alla resistenza scheletrica [3], tale studio ha senz'altro una notevole importanza.

Anche se questo studio è stato condotto su pochi casi senza avere come "end point primario" le fratture, tuttavia apre scenari importanti. La possibilità di riutilizzare romosozumab dopo un periodo di trattamento con un antiriassorbitivo, rappresenta senz'altro una opzione terapeutica importante, soprattutto in pazienti con osteoporosi severa.

Ringraziamenti Open access funding provided by Università degli Studi di Roma La Sapienza within the CRUI-CARE Agreement.

Nota della casa editrice Springer Nature rimane neutrale in riguardo alle rivendicazioni giurisdizionali nelle mappe pubblicate e nelle affiliazioni istituzionali.

Open Access This article is licensed under a Creative Commons Attribution 4.0 International License, which permits use, sharing, adaptation, distribution and reproduction in any medium or format, as long as you give appropriate credit to the original author(s) and the source, provide a link to the Creative Commons licence, and indicate if changes were made. The images or other third party material in this article are included in the article's Creative Commons licence, unless indicated otherwise in a credit line to the material. If material is not included in the article's Creative Commons licence and your intended use is not permitted by statutory regulation or exceeds the permitted use, you will need to obtain permission directly from the copyright holder. To view a copy of this licence, visit http://creativecommons.org/licenses/by/4.0/. 


\section{Bibliografia}

1. Cipriani C, Pepe J, Minisola S, Lewiecki EM (2018) Adverse effects of media reports on the treatment of osteoporosis. J Endocrinol Invest 41:1359-1364

2. Kendler DL, Bone HG, Massari F et al (2019) Bone mineral density gains with a second 12-month course of romosozumab therapy following placebo or denosumab. Osteoporos Int 30:2437-2448
3. Bouxsein ML, Eastell R, Lui LY et al (for the FNIH Bone Quality Project) (2019) Change in bone density and reduction in fracture risk: a meta-regression of published trials. J Bone Miner Res $34: 632-642$ 